\title{
An Analysis of Climatic Jump
}

\author{
By R. Yamamoto, T. Iwashima and Sanga N. K.
}

Laboratory for Climatic Change Research, Kyoto University

17-1 Ohmine-cho, Kitakazan, Yamashina-ku, Kyoto 607, Japan

\author{
M. Hoshiai \\ Physics Laboratory, Aichigakuin University, Nisshin-cho, Aichi-gun, Aichi-ken 470-01, Japan \\ (Manuscript received 22 November 1985, in revised form 13 February 1986)
}

\begin{abstract}
Lorenz $(1968,1976)$ stated that regime transition in almost-intransitivity of nonlinear climatic system may play an important role in climatic change, and he suggested that climatic change associated with the transition may appear in interannual variabilities. Referring to Lorenz's suggestion, we will treat abrupt changes of time mean, designated as climatic jumps. A quantitative definition of jump and simple method of its detection are presented, noting that the time of jump appearance can be specified within a margin of several years. Some jumps are detected in time series of seasonal mean data of surface air temperature, sea level pressure, precipitation, sunshine duration and maximum depth of snow-cover averaged spatially over Japan. The fact that jumps appear commonly in various climatic elements around 1950 suggests an association of these jumps with some abrupt changes of the atmospheric general circulation.

Concerning the cause of the jumps around 1950, we survey some change in external forcings. Big explosions of several volcanoes over the world occurred almost simultaneously with the jumps around 1950 after a pause of about 30 years. It is inadequate to assume that this volcanic activity would directly cause the jump in transitive system, because the possible climatic effect of volcanic eruption is mainly cooling and the jump of temperature is warming over Japan. However, further studies are needed for any definite conclusion on problem whether this reopening of volcanic activity would be a triggering action of the regime transition or not.
\end{abstract}

\section{Introduction}

Climate is a physical system of high nonlinearity, and should have some characteristics difficult to be interpreted by linear physics. From the viewpoint of non-linear physics, Lorenz $(1968,1976)$ did propose a non-deterministic theory of climatic change. In his theory, climatic system controlled by external forcings can be classified into two categories, transitivity and intransitivity, due to independency or dependency of the climate for infinite duration upon the initial conditions. Lorenz emphasized that in changes of climate for finite duration, a regime transition in almost-intransitivity should play an important role in such a way that the transition results in some climatic change without any change of external forcings. Iwashima et al. (1986), in their time-space spectral model of atmospheric general circulation affected by seasonal thermal forcing, demonstrated the possibility of existence of mutltiple stable solutions. This finding strengthens Lorenz's nondeterministic theory.

Lorenz (1976) suggested that in actual climate under remarkable seasonal forcing, the regime transition in almost intransitivity would appear in interannual variabilities. Referring to Lorenz's non-deterministic theory, the present authors (Yamamoto et al., 1985b) have proposed the concept of climatic jump for abrupt change of time average over a few decades, and noticed 
that time average over a few decades changes abruptly around 1950 in time series of surface air temperature data over Japan and the Arctic.

Neither a quantitative definition of the climatic jump nor its analysis procedure is yet established, because the most of previous climatic diagnoses are based upon premise of continuous changes of climate. A preliminary survey will be made for abrupt change of time average of surface air temperature, in Section 2 of the present paper. We will give a definition of the climatic jump, and present a quantitative method of jump detection in Section 3. In Section 4, this method will be applied to the time series of various climatic elements, and characteristics of the detected jumps will be discussed. Survey will be, in Section 5, attempted to ascertain the non-appearance of any changes in the external forcing corresponding to the jump, in order to verify the hypothesis that detected jumps might be perhaps associated with the regime transition in almost-intransitivity.

\section{Preliminary survey}

Survey is preliminarily made to see whether any abrupt change of time averaged temperature could be found or not in the interannual variabilities given in the literature. Yamamoto et al. (1985b) indicated an abrupt increase of the time averaged temperature in Japan (Japan Meteorological Agency, 1984) and a decrease in the Arctic (Kelly et al., 1982) around 1950. Diaz and Quayle (1980) noticed that the past climate for about 100 years in the United States can be divided into 3 sub-periods by comparatively abrupt changes around 1921 and 1950, and that the winter temperature in the Western part changes in opposite to that in the Eastern. Such opposite change in the United States is similar to those over Japan and the Arctic as was mentioned above.

Fig. 1 shows time series of temperature anomalies at 4 grid points along the meridian of $60^{\circ} \mathrm{W}$, which have been obtained in order to estimate Northern Hemisphere mean temperature in Yamamoto and Hoshiai (1980). Around 1950, relatively abrupt changes in long term trends indicated by arrows are noticed. The temperatures at $60^{\circ}$ and $70^{\circ} \mathrm{N}$ are rising, while those at $40^{\circ}$ and $50^{\circ} \mathrm{N}$ lowering, similarly to the opposite sense over the United States and to that between Japan and the Arctic. A remark should be made for urbanization effects, for abrupt rising of temperature around 1950 in Japan. Warming effect of urbanization is rather large in the great cities, and Fukui (1957) indicated that the magnitude is at most about $0.5^{\circ} \mathrm{C}$, except for Tokyo. However, we could find that temperature increasing at Sakai Minato (a small fishing port, Tottori-ken, Japan) was very similar to that in spatial average over Japan. The latter fact suggests that some other factor than urbanization should contribute to the abrupt rising of time averaged temperature around 1950. Another note should be made concerning the nonhomogenuity of the data which may be resulted from changes of observational site location. According to Kato and Mori (1971) and JMA (1981), it can be concluded that the influence of actual movement of observing site in Japan is less than $0.5^{\circ} \mathrm{C}$. It is quite probable that the effects of urbanization and observing site movement should be much diluted in spatially averaged temperature than that at a station. The final remark is made in regard to the effect of alternation of measuring instrument. On 1 January 1950, instrument of measuring the air temperature has been altered from non-ventilated thermometer onto ventilated one in Japan. The effect of this alternation should be less than $0.1^{\circ} \mathrm{C}$ after Saito (1956). These facts indicate that the abrupt changes around 1950 are not fictitious, but actual phenomena in the atmosphere.

\section{Definition of climatic jump and method of detection}

If the time average over a few decades before a year would differ, with sufficient statistical significance, from the time average after the same year, a discontinuity of the time average can be presumed within specified confidence limit. This is defined as "Climatic Jump". In order to detect such climatic jump from a time series of climatic data, we will adopt the following procedure similar to non-overlapping consecutive epoch analysis (Karl and Riebsame, 1984);

(1) Time mean $Y_{b}$ and its $95 \%$ confidence limit $\sigma_{b}$ are calculated over a time span 

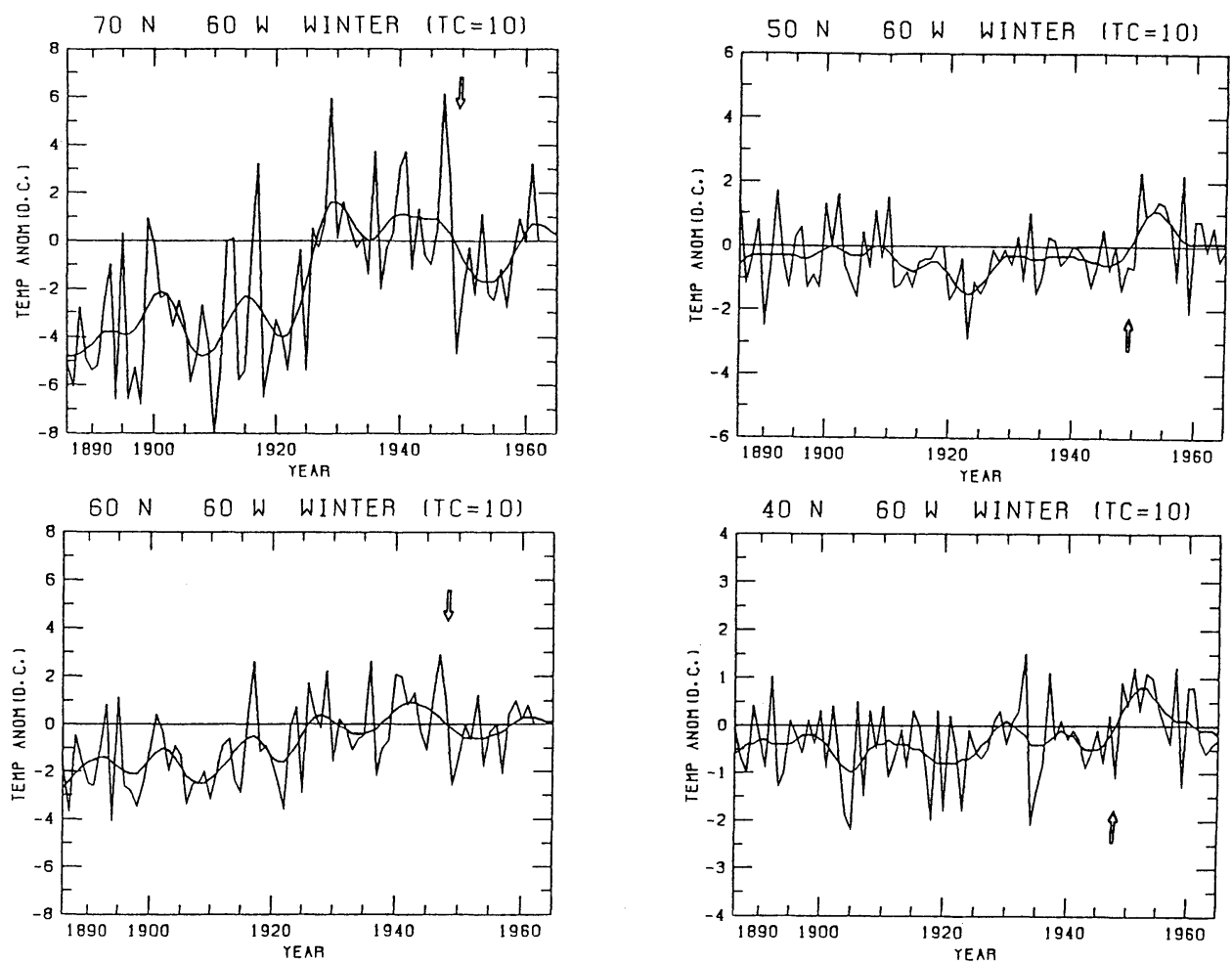

Fi.g 1 Time series of temperature anomaly at 4 grid points along the $60^{\circ} \mathrm{W}$ meridian. Thick curves are long-term variations obtained by low-pass filter with cut-off period 10 years.

of a few decades $R_{b}$ before the reference year.

(2) Time mean $Y_{a}$ and its $95 \%$ confidence limit $\sigma_{a}$ are calculated over a time span of a few decades $R_{a}$ after the same reference year.

(3) Signal-to-noise $(\mathrm{S} / \mathrm{N})$ ratio is defined by $\left|Y_{b}-Y_{a}\right| /\left(\sigma_{b}+\sigma_{a}\right)$ for the reference year.

(4) The reference year is consecutively displaced over whole period of available data, and time series of $\mathrm{S} / \mathrm{N}$ ratio are obtained.

(5) Detection of a jump is presumed for the $\mathrm{S} / \mathrm{N}$ ratio greater than 1.0 .

(6) Time of jump appearance is determined with the time of the maximum $\mathrm{S} / \mathrm{N}$ ratio, among various combinations of $R_{b}$ and $R_{a}$.

(7) It is understood that no jump is detected, if all the values of $\mathrm{S} / \mathrm{N}$ ratios are less than 1.0 .

In the present work, we specify that the averaging ranges $R_{b}$ and $R_{a}$ are 10,15,20, 25 and 30 years, referring to Karl and Riebsame's (1984) results on 10- to 20-year fluctuations of temperature and precipitation in the Contiguous United States.

We will give an example of detecting a jump for summer precipitation averaged over Japan in Fig. 2. Figs. $2 a$ and $2 b$ give time series of 3 month precipitation anomaly from 80-year mean (1901-1980), and the $\mathrm{S} / \mathrm{N}$ ratio and difference of means $\left(Y_{a}-Y_{b}\right)$ over 25 years, for reference years from 1930 to 1952, respectively. The $\mathrm{S} / \mathrm{N}$ ratios are greater than 1.0 from 1946 to 1949 with its maximum 1.2 in 1947. In the same year, the difference of 25 -year means is also the maximum of about $90 \mathrm{~mm} /$ 3 months. Referring to the abrupt increase of long-term trend from early 1940 s to early 1950 s in Fig. 2a, we can apparently regard this maximum of $\mathrm{S} / \mathrm{N}$ ratio as an appearance of a climatic jump. This example also shows that the simple method proposed here fulfills satisfactorily the function of detecting climatic jump. It should 
(a)

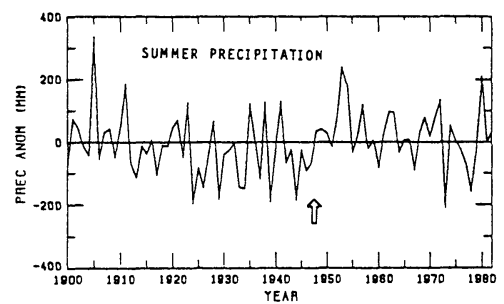

(b)

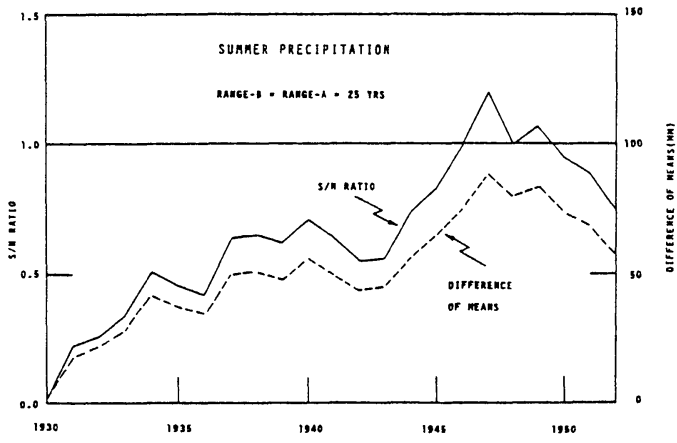

Fig. 2 Examples of the jump detection procedure for summer perecipitation. Time series of the anomaly is shown in (a), and those of $\mathrm{S} / \mathrm{N}$ and difference of means in (b).

be noted that precise specification of year of jump occurrence is meaningless, because the year-to-year variabilities are usually so large as to obscure the exact time of jump appearance. Then we should specify the time of jump occurrence with a broad range of several years.

\section{Data}

The climatic jump in question is expected to be global, although the sense of the jump (increasing or decreasing) may vary from region to region. Since observational data are, in general, contaminated with local irregularities and the observational errors, it is necessary to examine whether they would have a possibility to veil the jump so that it might disappear in remarkable year-to-year variability.

Such local irregularities and the errors can be, in principle, estimated by a method using the structure functions (Gandin, 1963; and Yamamoto, 1980). This method shows that the twice of square of the local irregularities and the errors is, on the average, equal to the value of structure function for the vanishing distance between a pair of stations. According to the present authors' experience in analysis of climatic data, systematic difference of local climate results in large scattering of structure function, which should disturb any precise estimate of the local irregularities. Notwithstanding, rough estimate of the local irregularities and the errors can be made, with the following results: the upper bounds of errors in the data at a station are $1.0^{\circ} \mathrm{C}, 1.2 \mathrm{mb}, 90 \mathrm{~mm}, 70 \mathrm{hr}$ and $12 \mathrm{~cm}$, for the 3 -month mean temperature, 3-month mean sea level pressure, 3-montn precipitation, 3-month sunshine duration and 3-month mean of monthly maximum depth of snowcover, respectively.

These local irregularities in station data may possibly still disturb the jump detection. The local irregularities in the spatial mean should decrease in inverse proportion to the square root of number of stations. Therefore, we decide to detect the jump for the data averaged spatially over Japan, rather than the data at a single station. This is consistent with the premise that the jump is not local, but regional or larger. The stations used in spatial average are distributed rather uniformly over Hokkaido, Honshu, Shikoku and Kyushu, and the number falls in range from 49 to 60 , except for maximum depth of snowcover. The data of maximum depth of snowcover, restricted to winter season, are spatially averaged over 9 stations along the Japan Sea coast of Honshu. The data from 1900 to 1982 in Japan are used here for jump detection. Since the longest averaging range is 30 years, detecting jump is possible only for a 23 year span from 1930 to 1952 .

\section{Results}

Jump detection by the method proposed in the Section 3 is attempted for seasonal data of temperature, sea level pressure, precipitation, sunshine duration and maximum depth of snowcover from 1930 to 1952 . The detected jumps are listed in Table 1. It is noticed that a jump is found from 1947 to 1952 in all the climatic elements taken here, in addition to that of sunshine duration in the 1930s. Fig. 3 shows examples of the detected jumps, for winter tem- 
Table 1 Detected Jumps from 1930 to 1952.

\begin{tabular}{|c|c|c|c|c|c|c|c|}
\hline \multirow{2}{*}{\multicolumn{2}{|c|}{\begin{tabular}{|l|} 
\\
$\begin{array}{l}\text { Number of stations } \\
\text { for mean }\end{array}$ \\
\end{tabular}}} & \multirow{2}{*}{$\begin{array}{c}\begin{array}{c}\text { Tem- } \\
\text { perature }\end{array} \\
60\end{array}$} & \multirow{3}{*}{$\begin{array}{c}\text { Pressure } \\
56\end{array}$} & \multirow{3}{*}{$\begin{array}{c}\begin{array}{c}\text { Precipi- } \\
\text { tation }\end{array} \\
60\end{array}$} & \multicolumn{2}{|c|}{$\begin{array}{l}\text { Sunshine } \\
\text { Duration }\end{array}$} & \multirow{2}{*}{$\begin{array}{c}\text { Snow } \\
\text { Depth }\end{array}$} \\
\hline & & & & & & & \\
\hline Winter & $\begin{array}{l}\text { Year } \\
\mathrm{S} / \mathrm{N} \\
\text { Jump } \\
R_{b} \\
R_{a}\end{array}$ & $\begin{array}{c}1948 \\
1.55 \\
+1.0^{\circ} \mathrm{C} \\
30 \mathrm{yrs} \\
25 \mathrm{yrs}\end{array}$ & & & $\begin{array}{r}1938 \\
1.64 \\
+43 \mathrm{hr} \\
30 \mathrm{yrs} \\
10 \mathrm{yrs}\end{array}$ & $\begin{array}{c}1949 \\
1.09 \\
-34 \mathrm{hr} \\
10 \mathrm{yrs} \\
10 \mathrm{yrs}\end{array}$ & $\begin{array}{r}1948 \\
1.33 \\
-14 \mathrm{~cm} \\
30 \mathrm{yrs} \\
10 \mathrm{yrs}\end{array}$ \\
\hline Spring & $\begin{array}{l}\text { Year } \\
\mathrm{S} / \mathrm{N} \\
\text { Jump } \\
R_{b} \\
R_{a}\end{array}$ & $\begin{array}{c}1950 \\
2.04 \\
+0.8^{\circ} \mathrm{C} \\
30 \mathrm{yrs} \\
30 \mathrm{yrs}\end{array}$ & & $\begin{array}{l}1950 \\
1.62 \\
+65 \mathrm{~mm} \\
25 \mathrm{yrs} \\
10 \mathrm{yrs}\end{array}$ & $\begin{array}{r}1930 \\
1.26 \\
+42 \mathrm{hr} \\
30 \mathrm{yrs} \\
15 \mathrm{yrs}\end{array}$ & $\begin{array}{c}1950 \\
1.26 \\
-36 \mathrm{hr} \\
25 \mathrm{yrs} \\
20 \mathrm{yrs}\end{array}$ & \\
\hline Summer & $\begin{array}{l}\text { Year } \\
\mathrm{S} / \mathrm{N} \\
\mathrm{Jump} \\
R_{b} \\
R_{a}\end{array}$ & & $\begin{array}{l}1949 \\
1.04 \\
-0.7 \mathrm{mb} \\
25 \mathrm{yrs} \\
20 \mathrm{yrs}\end{array}$ & $\begin{array}{r}1947 \\
1.20 \\
+89 \mathrm{~mm} \\
25 \mathrm{yrs} \\
25 \mathrm{yrs}\end{array}$ & $\begin{array}{r}1931 \\
1.05 \\
+47 \mathrm{hr} \\
30 \mathrm{yrs} \\
20 \mathrm{yrs}\end{array}$ & $\begin{array}{c}1952 \\
1.88 \\
-72 \mathrm{hr} \\
30 \mathrm{yrs} \\
25 \mathrm{yrs}\end{array}$ & \\
\hline Autumn & $\begin{array}{l}\text { Year } \\
\mathrm{S} / \mathrm{N} \\
\text { Jump } \\
R_{b} \\
R_{a}\end{array}$ & & & & $\begin{array}{r}1934 \\
1.31 \\
+43 \mathrm{hr} \\
30 \mathrm{yrs} \\
10 \mathrm{yrs} \\
\end{array}$ & & \\
\hline
\end{tabular}

perature, summer sea level pressure, spring precipitation, summer sunshine duration and maximum depth of snowcover, where the detected jumps are indicated by arrows. Superimposed upon the time series of anomaly, time averages $Y_{b}$ and $Y_{a}$ (full lines) and the $95 \%$ confidence limits (broken lines) are computed. The confidence intervals before and after the jumps are separated clearly from each other, because of the $\mathrm{S} / \mathrm{N}$ ratios greater than 1.0. These illustrate that the detected jumps are not produced accidentally by averaging process of rather random interannual variabilities, but could be a manifestation of actually occurring phenomena in the atmosphere.

There are probably some jumps around 1920, as seen in time series of sunshine duration (Fig. 3d) and others. Because of limited length of observational data, these cannot be discussed here. It is interesting to examine whether the jumps in question here would be accompanied with some abrupt change of higher moment like variance. Discontinuity of variance can be found simultaneously with the jump of maximum snowcover in 1948, with statistical significance of $95 \%$ confidence. However, no significant discontinuity of variance is found for other climatic elements.

The fact that jumps appear in all the 5 climate elements commonly during 6 years form 1947 to 1952 suggests strongly some close association of the jumps with some abrupt change of the atmospheric general circulation, referring to rough specification of jump occurrence time in a broad range of several years. It should be noted that sunshine duration jump may be perhaps 



Fig. 3 Examples of detected jumps for spring temperature (a), summer sea level pressure (b), spring precipitation (c), summer sunshine duration (d) and maximum depth of snowcover (e). Solid lines are time averages and broken ones $95 \%$ confidence limits.

associated with the change of global cloud distribution, and the radiation balance might be eventually affected. Although the jumps of sunshine duration are found in the 1930s, no detectable jump is found for other climatic elements. Further studies are needed in order to examine whether or not this jump of sunshine duration in the 1930s are associated with abrupt change of the atmospheric general circulation.

\section{Discussion}

It is interesting to examine whether or not the jumps in question are associated with the regime transition in system of almost-intransitivity, or changes in transitive system caused directly by abrupt changes of some external forcing. Most powerful external forcings with possible direct climatic influence are the solar constant, loading of the stratospheric volcanic aerosols and increasing concentration of carbon dioxide in the atmosphere (Joint Organizing Committee, WMOICSU, 1975). In intransitivity and almost-intransitivity, it is possible that a jump might appear without any abrupt changes of external forcings.

Validity of the assumption will be examined that the present climate would be transitive and change in quasi-equilibrium with external forcing (Mitchell, 1983). If no abrupt change in external forcings could be found almost simultaneously with jump, and the assumption could not be justified, then alternate assumption would become more acceptable that the climate would be intransitive or almost-intransitive.

Survey will be made whether any abrupt change could be found almost simultaneously with the jump around 1950. The increase of the carbon dioxide is too gradual (Neftel et al., 1985) to cause directly any jump in question here. It is examined whether any noticeable difference of the solar activity between both a few decades before and after 1950 could be found. Reliable measurement of the solar constant was not available until operation of cavity pyrheliometer in 1978 (Hickey et al., 1982), and we cannot examine any changes of solar constant around 1950. Although Gilliland (1982) related the solar radius change to the climatic change, no abrupt change can be expected in the radius which has a predominant period of about 80 years (Gilliland, 1982). Hoyt (1980) assumed that solar umbra/penumbra ratio might be related closely with solar irradiance. In time series of this ratio given by Hoyt (1980), a noticeable difference can be found between both decades before and after the middle of 1940s. However, there is no good correspondence between the ratio and temperature change in time scale of a few decades concerned here. And a solar physicist (Kawaguchi, 1984) discussed critically Hoyt's hypothesis and mentioned that further research in solar physics should be made for the hypothesis to be verified. Some solar activities are reflected on the geomagnetic disturbances (Valley, 1965). Examining the time series of montly mean of equivalent 
planetary amplitude Ap, reproduced from Lehnhart Tape of NOAA, no noticeable evidence can be found for any variability to result directly in climatic jumps around 1950.

Another powerful external forcing is volcanic explosions producing the stratospheric aerosol loading. It is difficult to acquire any reliable time series of the aerosol loading. However, it is noticed that a pause of volcanic activity did persist for about 30 years from the last half of the 1910 s to the middle of the 1940s (Lamb, 1970 and Simkin et al., 1981). Various estimates (Mitchell, 1970, Oliver, 1976 and Yamamoto, 1980) show that relatively clean stratosphere has begun to be polluted by volcanic aerosols since middle of the 1940s. This fact suggests some association between the jumps around 1950 and the reopening of volcanic activity. Actually, hemisphere mean temperature has increased by several tenth of degree during the pause of volcanic activity, and has decreased almost simultaneously with reopening of the activity (Yamamoto and Hoshiai, 1980, Jones et al., 1982, and Folland et al., 1984).

However, the magnitude of temperature jumps averaged over Japan is about $1^{\circ} \mathrm{C}$ and much greater than change of hemispherical mean, and the sense of jumps varies in region to region. These suggest that the reopening of volcanic activity might hardly directly cause the jumps in transitive system, but play a triggering action in regime transition of almost intransitivity, which would eventually cause jump. Further studies are needed to confirm the triggering action of the reopening of volcanic activity.

\section{Concluding remarks}

A quantitative definition of climatic jump is given for statistically significant discontinuity of time averages. A simple method, with satisfactory function of detecting jump, is presented, noticing that the time of jump appearance can be specified in a broad range of several years. The present paper has mainly dealt with the observational data in Japan, and no findings concerning other regions over the globe are presented, except for temperature. It can be seen that the temperature jump around 1950 is not confined in the area of Japan, but is also detected in other regions, although sense of jump is not the same.

No jump of sea level pressure was detected except for summer. This fact does not necessarily deny an assumption that the jump could be a manifestation of an abrupt change of the atmospheric general circulation. This is because the sense of jump should not necessarily be uniform over the globe, as seen in temperature jump around 1950, and because node of the jump distribution would perhaps locate over Japan.

Concerning the cause of the jump around 1950 , some changes of possible external forcings are surveyed, and reopening of volcanic activity is noticed in the last half of the 1940s. It is probable that this reopening might play a triggering action of regime transition in almost-intransitivity, which eventually result in jumps. This should be confirmed by further studies in future.

\section{Acknowledgements}

The climatic data analyzed here are kindly furnished to us by the Statistical Division of the Japan Meteorological Agency. The Lenhart Tape of NOAA containing Ap index data could be processed by courtesy of Dr. T. Araki of Data Analysis Center for Geomagnetism and Space Magnetism, Kyoto University. Some useful discussions were given in colloquium of Meteorological Laboratory of Department of Geophysics, Kyoto University. A valuable comment concerning the effects of alternation of measuring instruments was given by Dr. K. Ninomiya and Mr. Y. Mano of Japan Meteorological Agency. The present work is financially supported by the Scientific Fund from the Ministry of Education, Culture and Science. The computations reported in the present paper were performed with use of an FACOM M340R computer system at the Laboratory for Climatic Change Research, Kyoto University.

\section{References}

Diaz, H. F. and R. G. Quayle, 1980: The climate of the United States since 1885: Spatial and temporal changes. Mon. Wea. Rev., 108, 249-266.

Folland, C. K., D. E. Parker and F. E. Kates, 1984: Worldwide marine temperature fluctuations $1856-$ 1981. Nature, 310, 670-673.

Fukui, E., 1957: Increasing temperature due to the 
expansion of urban areas in Japan. J. Met. Soc. Japan, 75th Anniversary Volume, 336-341.

Gandin, L. S., 1963: Objective analysis of meteorological fields. Israel Program for Scientific Translation, Jerusarem. 242 pp.

Gilliland, R. L., 1982: Solar, volcanic, and $\mathrm{CO}_{2}$ forcing of recent climatic changes. Clinatic change, 4, 111131.

Hickey, J. R., B. M. Alton, F. J. Griffin, H. Jacobwitz, P. Pellegrino, R. H. Maschhoff, E. A. Smith and T. H. Vonder Haar, 1982: Extraterrestrial solar irradiance variability: two and one-half years of measurements from Nimbus 7. Solar Energy, 28, 443-445.

Hoyt, D. V., 1980: Climatic change and solar variability. Weatherwise, 33, 65-69.

Iwashima, T. and R. Yamamoto, 1986. Time-space spectral general circulation model; I. Time-space spectral model of low-order barotropic system with periodic forcing. J. Met. Soc. Japan 64, 183-196.

Japan Meteorological Agency, Division of Observations, 1981: Report for Investigation of Climatic Change (I), Reference for Interpretation, No. 8 (in Japanese). Japan Meteorological Agency, Tokyo.

Japan Meteorological Agency, 1984: Unusual Weather Report, 1984 (in Japanese). Printing Office of Ministry of Finance, Tokyo, 294 pp.

Joint Organizing Committee, WMO-ICSU, 1975: The physical basis of climate and climate modelling. GARP Pub. Ser. 16, WMO.

Jones, P. D., T. M. L. Wigley and P. M. Kelly, 1982: Variations in surface air temperature: Part 1. Northern hemisphere, 1881-1980. Mon. Wea. Rev., 110, 59-70.

Karl, T. R. and W. E. Riebsame, 1984: The identification of 10- to 20-year temperature and precipitation fluctuations in the contiguous United States.

J. Climate and Appl. Met., 23, 950-966.

Kato, H. and I. Mori, 1971: On the rising trends of air temperature in large cities. Tenki, 18, 597-601 (in Japanese).

Kawaguchi, I., 1984: Solar physicist's criticism on relationship of umbra/penumbra ratio with the solar irradiance (Private communication).

Kelly, P. M., P. D. Jones, C. B. Sear, B. S. G. Cherry and R. K. Tavakol, 1982: Variations in surface air temperature; Part 2. Arctic regions, 1881-1980. Mon. Wea. Rev., 110, 71-83.

Lamb, H. H., 1970: Volcanic dust in the atmosphere, with a chronology and assessment of its meteorological significance. Phil. Trans. Roy. Soc., A, 266,
$425-533$.

Lorenz, E. N., 1968: Climatic determinism. Met. Monogr. 8 , No. $30,1-3$. , 1976: Nondeterministic theories of climatic change. Quat. Res., 6, 495-506.

, 1984: Some aspects of atmospheric predictability. Problems and Prospects in Long and Medium Range Weather Forecasting, ed. by D. M. Burridge and E. Kallen, Springer, pp. 1-20.

Mitchell, J. M. Jr., 1970: A preliminary evaluation of atmospheric pollution as a cause of the global temperature fluctuation of the past century. Clobal Effects of Environmental Pollution, ed. by S. F. Singer, D. Reidel Publ., Dortrecht.

, 1983: Empirical modelling of effects of solar variability, volcanic events, and carbon dioxide on global-scale temperature since A.D. 1880. Weather and Climate Response to Solar Variations, ed. by B. M. McCormac. Colorado Assoc. Univ. Press, Boulder, Colorado, 265-272.

Neftel, A., E. Moor, H. Oeschger and B. Stauffer, 1985: Evidence from polar ice cores for the increase in atmospheric $\mathrm{CO}_{2}$ in the past two centuries. Nature, 315, 45-47.

Oliver, R. C., 1976: On the response of hemispheric mean temperature to stratospheric dust: An empirical approach. J. Appl. Met., 15, 933-951.

Saito, R., 1956: On the homogenuity of observed values of air temperature. J. Met. Res., 8, 20-24. (in Japanese with English abstract).

Simkin, T., L. Siebert, D. Bridge, C. Newhall and J. H. Latter, 1981: Volcanoes of the World. Hutchinson Ross., Stroudburg, 233 pp.

Valley, S. L., 1965: Handbook of Geophysics and Space Environments. McGraw-Hill, New York.

Yamamoto, R., 1980: Variability of northern hemisphere mean surface air temperature during recent two hundred years. Statistical Climatology, ed. by S. Ikeda et al., Elsevier, Dordrecht, 388 pp.

Yamamoto, R. and M. Hoshiai, 1980: Fluctuations of the northern hemisphere mean surface air temperature during recent 100 years, estimated by optimum interpolation. J. Met. Soc. Japan, 58, $187-$ 193.

Yamamoto, R., T. Iwashima, Sanga, N. K. and M. Hoshiai, 1985a: An estimate of climatic noise. $J$. Met. Soc. Japan, 63, 1147-1156. and $1985 \mathrm{~b}$ : Climatic jump: a hypothetical concept in climate diagnosis. J. Met. Soc. Japan, 63, 1157-1160. 


\section{気候ジャンプの解析}

\section{山元龍三郎・岩嶋樹也・サンガ N.K.}

京都大学理学部附属気候変動実験施設

\section{星合 誠}

愛知学院大学教養部物理学教室

気候は高度の非線型システムであるので, 非線型物理システムの振る舞いの研究に基づく Lorenz （1968）の非決定論的気候変動論は, 重要な意義を持つ。Iwashima ら (1986)は, 熱的強制の季節変化の下 で，大気大循環の時間・空間スペクトルモデルが，安定な多重解を持つ事を示したが，この結果はLorenz の非決定論的気候変動論を支持するものである。Lorenz(1976) は, 特に準自律性 (Almost Intransitivity)におけるレジームの遷移が, 気候変動において重要な役割を演じている可能性を強調し， それが実際に発現しているならば，年々変化における時間平均の唐突な変化として現れるだろう事を示 唆している。

今までの気候の診断的研究が連続的変化を前提として進められたのと対照的に，この論文では，Lorenz(1976) の示唆に従って時間平均の有意な不連続を取り上げる。或る年を境にして，それ以前の10年 またはそれ以上の期間の時間平均值が, それ以後の時間平均值と比較して統計的に有意な差を示す場合 を「気候ジャンプ」と呼ぶ事にした。時間平均に対する $95 \%$ の信頼限界を採用して S / N 比を導入し, 気候ジャンプを検出する方法を提示した。顕著な年々変化のために気候ジャンプの発現時期を 1 年単位 で指定する事は無意味である事を注意した。1900年以降の北海道・本州・四国・九州において空間平均 をした季節平均気候データに対して，気候ジャンプの検出を試みた。その結果，気温・海面気圧・降水 量・日照時間・最大積雪哚において，1950年頃に集中して気候ジャンプが検出された。同じ時期に気候 ジャンプが各種の気候要素に共通して発現している事実から，これらの気候ジャンプは，大気大循環の 唐突な変化の一つの現れだと考えられる。

1950年頃の気候ジャンプが Lorenz の準自律性におけるレジームの遷移に伴う現象である事を確かめ るためには，現在の気候が他律的でない事を確かめる必要があり，その頃に顕著な変化が外部要因に認 められるかどうかを調べた。1910年代の後半から1940年代の半ばまで大規模な火山噴火が無かったが, 1940年代後半以後大噴火が頻発した。即ち，約30年間大量の火山性エアロゾルの注入の無かった成層圈 が, 気候ジャンプの発現の直前の火山活動の再開によって, 多量のエアロゾルを含み始めたと考えられ る。この火山性成層圈エアロゾルの急増が, 気候ジャンプ発現のトリガーになった可能性がある。しか し，これを確認するためには全地球的なデー夕解析が必要である。 